\title{
URBAN FLOOD HAZARD MAP USING GIS OF MUANG SUKHOTHAI DISTRICT, THAILAND
}

\author{
Charatdao KONGMUANG', Sarintip TANTANEE ${ }^{2}$ (D, Kamonchat SEEJATA ${ }^{3}$
}

DOI: $10.21163 / G T \_2020.151 .13$

\begin{abstract}
:
Urban flood is one of the most challenge tasks for cities that needs the complex decision support system based on the integration among physical, social parameters and technical knowledge. It needs the analysis on flood hazard map to set up the emergency response plan. Most of communities in Thailand originated along the river of which urban flood is caused by both overflowing from river bank and ineffective drainage system. The most severe urban flood in Thailand occurs in Muang district of Sukhothai province. Because the city locates along Yom river basin where is no regulated dam upstream. Since there are the limitations on the technical support of local organizations. The aim of this paper, therefore, is to generate flood hazard map by coupling flood frequency analysis with GIS that the local officer can easily develop by themselves. Flood frequency analysis proves it can be an alternative method for flood hazard map generating. With the case study of Muang Sukhothai district, the accuracy of this method is $88.83 \%$. The obtained flood hazard map will be the basic information for the decision maker not only on flood emergency response plan but also on prioritizing of budget allocation for flood protection system.
\end{abstract}

Key-words: Urban flood, Flood emergency response plan, Flood hazard map, Sukhothai flood.

\section{INTRODUCTION}

Flood is one of the most threatening and damaging natural disasters globally that impacts negatively upon the activities of human lives, with inundation leading to disastrous consequences including the loss of lives and destruction of property (Dadson et. al, 2017). Flood hazard is expected to increase in frequency and magnitude because of the impacts of climate change (Dinh et al., 2012). Then it requires various responses including construction for downstream flood defences, forecasting (for warning and evacuation), and land-use management for upstream land use changes and runoff characteristics (Kidson and Richards, 2005). Floods occur because of the rapid accumulation and release of runoff waters from upstream to downstream, caused by very heavy rainfall (Ouma and Tateishi, 2014; Şarpe and Haidu, 2017). Urban areas in particular suffer from a relatively high flood risk because of high population number and density, a lot of economic activities, infrastructure and property values (Pelling, 2003; Nusit et al., 2019).

\footnotetext{
${ }^{1}$ Naresuan University, Department of Natural Resources and Environment, Faculty of Agriculture, Natural Resources and Environment, Phitsanulok, Thailand, charatdao@gmail.com;

${ }^{2}$ Naresuan University, Excellent Center on Energy Technology and Environment, Faculty of Engineering,Phitsanulok, Thailand, sarintipt@nu.ac.th;

${ }^{3}$ Naresuan University, Department of Civil Engineering, Faculty of Engineering, Phitsanulok, Thailand, kamonchatseejata@gmail.com
} 
Impacts of urban floods are significant in terms of economic losses. There is a direct relationship between urbanisation and hydrological characteristics; decreased infiltration, increase in runoff, increase in flood frequency and flood height (Alaghmand et al., 2010; Ouma and Tateishi, 2014, Haidu and Ivan, 2016a). Increasing discharge is directly related to the increase in urbanised areas (Phetprayoon et al., 2010; Haidu and Ivan, 2016b). Urbanisation tends to increase peak flood flows because of reduced infiltration under paved areas and rapid flow over the surface (Dadson et al., 2017, Kumar et al., 2013).

Urban flood due to overflow of the riverbank in cities is not an isolated phenomenon but closely related with overall basin characteristics. The city of Sukhothai, located in lower Yom river basin in lower northern of Thailand, frequently suffers from floods due to the low retention capability of the upstream area (lacking of the regulated dam) and the narrow basin cross section in the downstream area (Sriariyawat et al., 2013; Seejata et. al., 2019). The Yom river, a tributary of the Chao Phraya River, is approximately $736 \mathrm{~km}$ long with the average flow capacity of the main channel varies from $220 \mathrm{~m}^{3} / \mathrm{s}$ to $2,000 \mathrm{~m}^{3} / \mathrm{s}$. As Sriariyawat et al. (2013) pointed out that the segment from Phrae province to Sukhothai province has a capacity of 1,000-2,000 $\mathrm{m}^{3} / \mathrm{s}$, whereas the segment from Sukhothai province to Phitsanulok province has a capacity of only $220-300 \mathrm{~m}^{3} / \mathrm{s}$. Therefore, when there is heavy rainfall over the upstream area, it causes an overflow of the riverbanks, erosion and severe flooding in Sukhothai urban area.

With urban development, impermeable surface areas decrease infiltration and increase the rate and volume of surface runoff (Fitzpatrick et al., 2005). Klemešová et al. (2014) noted that flood hazard map is one of the preventive instruments for assessment and management of flood risks. The problem is that there are still have limitations on technical support of local organizations in Sukhothai province. Having flood hazard and flood extent maps could help them in terms of dicision support system to prioritise the response plan and budget allocation for the protection system. The aim of this study, therefore, is to generate flood hazard map by coupling frequency analysis with Geographic Information System (GIS) that the local officer can easily develop by themselves as well as can be the information for decision maker on flood preparedness and responses.

\section{STUDY AREA AND DATA}

\subsection{Study area}

Sukhothai province is most famous for its historical city, the first capital of Thailand. Sukhothai Historical Park in Muang district is now a UNESCO World Heritage Site. Muang Sukhothai is the capital district that can be seen as an urban area of Sukhothai province. It is located in lower Yom river basin in lower northern of Thailand (Fig.1). It is divided into 10 sub-districts, which are further subdivided into 98 villages. Total area of Muang Sukhothai is $553.38 \mathrm{~km}^{2}$ with the population of 104,328. It has the highest population density of 188.53/ $\mathrm{km}^{2}$ accounting for $18.82 \%$ of the Sukhothai province that covers approximately $6,664.48$ $\mathrm{km}^{2}$ with the population of 597,257 (Tab. 1).

\subsection{Data}

According to Seejata, et al. (2019) and previous studies, eight conditioning parameters were selected for flood hazard analysis including rainfall, elevation, slope, land use, soil drainage, drainage density, distance from drainage and road density (Anucharn and 
Iamchuen, 2017; Cao et al., 2016; Das, 2019; Duangpiboon et al., 2018; Khosravi et al., 2016; Lee et al., 2018; Sahana and Patel, 2019; Samanta et al.,2018; Samanta, 2018; Shafapour et al., 2019; Tehrany et al., 2015; Youssef et al., 2016). Table 2 and Fig. 2 give more detailed on data used in this analysis.

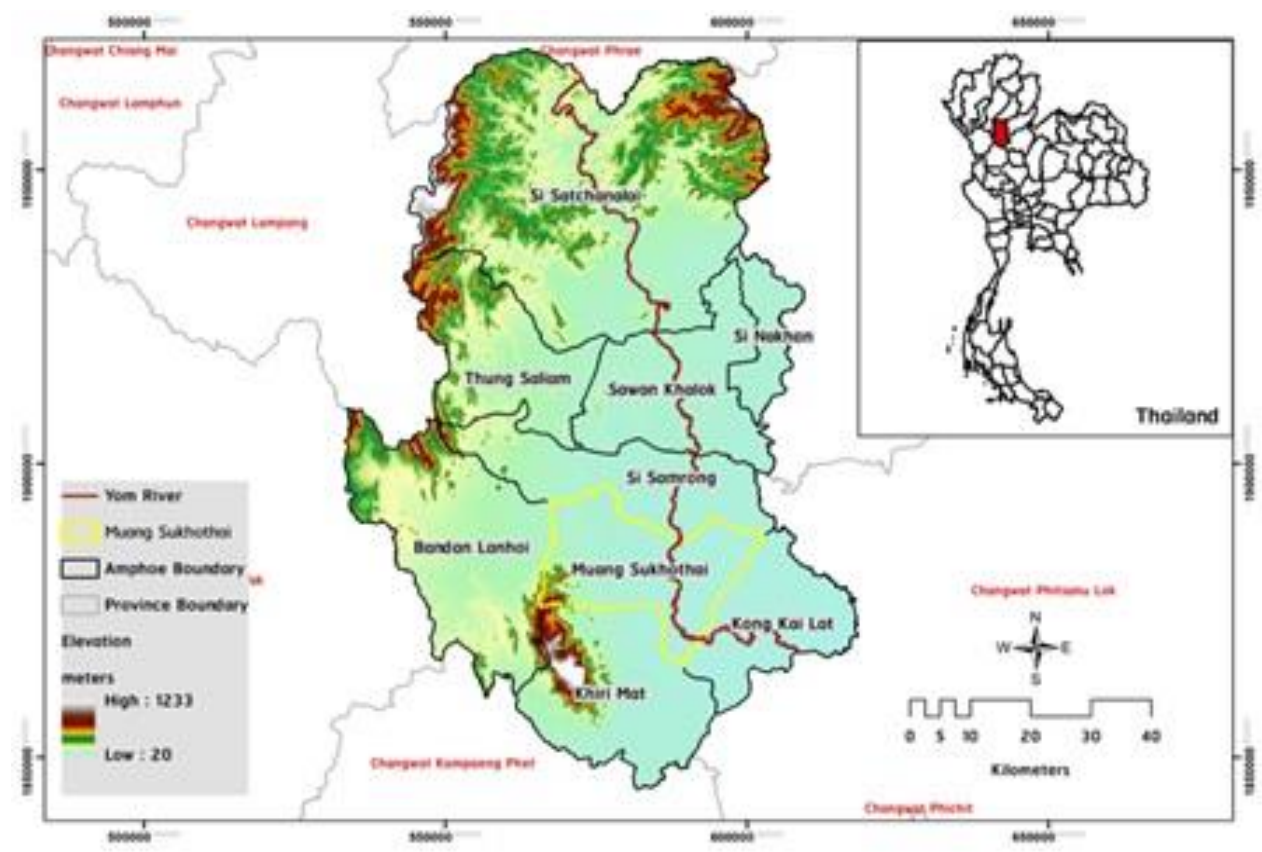

Fig. 1. Study area of Muang Suhkothai district, Thailand.

Area and population of Sukhothai province.

Table 1.

\begin{tabular}{|l|c|c|c|c|}
\hline \multicolumn{1}{|c|}{ District } & Area & Pop & Pop Density $\left(\mathbf{p e r} \mathbf{~ k m}^{\mathbf{2}}\right)$ & \% \\
\hline Muang Sukhothai & 553.38 & 104,328 & 188.53 & 18.82 \\
\hline Kong Krailat & 449.10 & 64,308 & 143.19 & 14.30 \\
\hline Si Nakhon & 183.25 & 26,177 & 142.85 & 14.26 \\
\hline Sawankhalok & 620.06 & 83,919 & 135.34 & 13.51 \\
\hline Si Samrong & 558.50 & 71,110 & 127.32 & 12.71 \\
\hline Thung Saliam & 583.94 & 49,492 & 84.75 & 8.46 \\
\hline Khiri Mat & 679.73 & 56,864 & 83.66 & 8.35 \\
\hline Ban Dan Lan Hoi & 923.24 & 47,960 & 51.95 & 5.19 \\
\hline Si Satchanalai & $2,113.29$ & 93,099 & 44.05 & 4.40 \\
\hline \multicolumn{1}{|c|}{ Total } & $\mathbf{6 , 6 6 4 . 4 8}$ & $\mathbf{5 9 7 , 2 5 7}$ & $\mathbf{8 9 . 6 2}$ & $\mathbf{1 0 0 . 0 0}$ \\
\hline
\end{tabular}

Source: National Statistical Office of Thailand 
Table 2.

Data and Sources.

\begin{tabular}{|c|l|}
\hline Data & \multicolumn{1}{|c|}{ Detailed and Sources } \\
\hline Rainfall & $\begin{array}{l}\text { Average rainfall (Between1988-2017) obtained from Thai Meteorological } \\
\text { Department (TMD) }\end{array}$ \\
\hline Elevation & $\begin{array}{l}\text { 30x30 meter spatial resolution from the Digital Elevation Model of Shuttle } \\
\text { Radar Topography Mission }\end{array}$ \\
\hline Slope & Derived from the Digital Elevation Model \\
\hline Land use & $\begin{array}{l}\text { (1) Agricultural land (2) Forest land (3) Urban land (4) Water (5) } \\
\text { Miscellaneous land (From Land Development Department) }\end{array}$ \\
\hline Soil drainage & $\begin{array}{l}\text { (1) No survey (2) Poorly to somewhat poorly drained (3) well to moderately } \\
\text { well-drained (4) Very well-drained (5) Urban area (6) Miscellaneous area } \\
\text { (7) Water (From Land Development Department) }\end{array}$ \\
\hline $\begin{array}{c}\text { Drainage density } \\
\text { Distance from } \\
\text { drainage }\end{array}$ & $\begin{array}{l}\text { Derived from the Geo-Informatics and Space Technology Development } \\
\text { Agency (GISTDA) }\end{array}$ \\
\hline Road density & Five concentric buffers (each of 1,000 meter width). \\
\hline
\end{tabular}

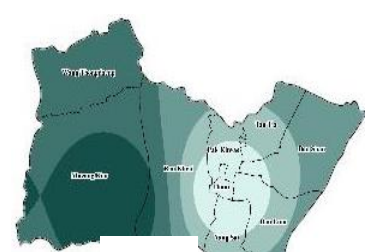

(a)
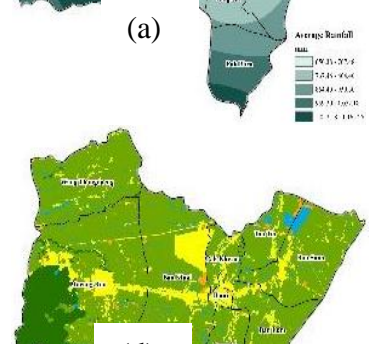

(d)
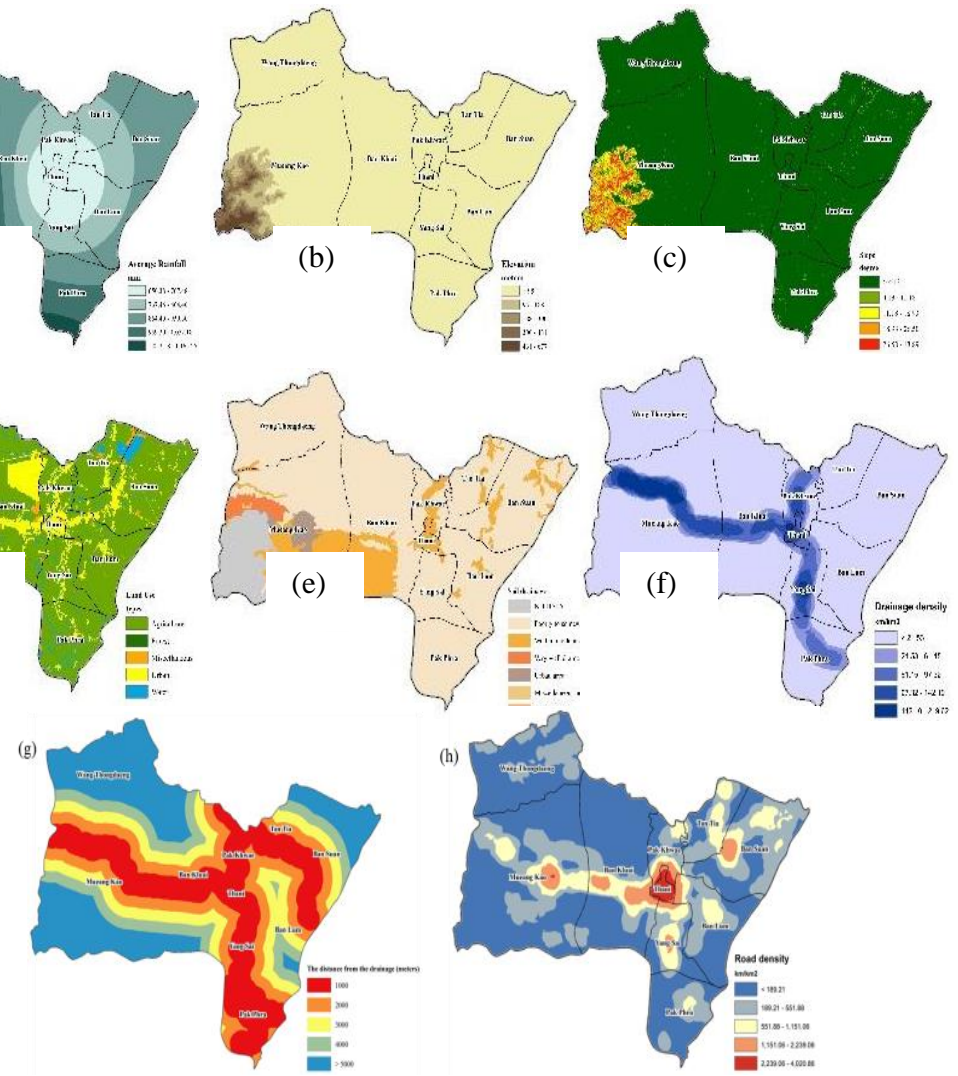

Fig. 2. Eight conditioning parameters: (a) rainfall, (b) elevation, (c) slope, (d) land use, (e) soil drainage, (f) drainage density, (g) distance from drainage and (h) road density. 


\section{METHODOLOGY}

To generate the flood hazard map, this study applied the frequency ratio (FR) method. Fig. 3 shows the methodology framework.

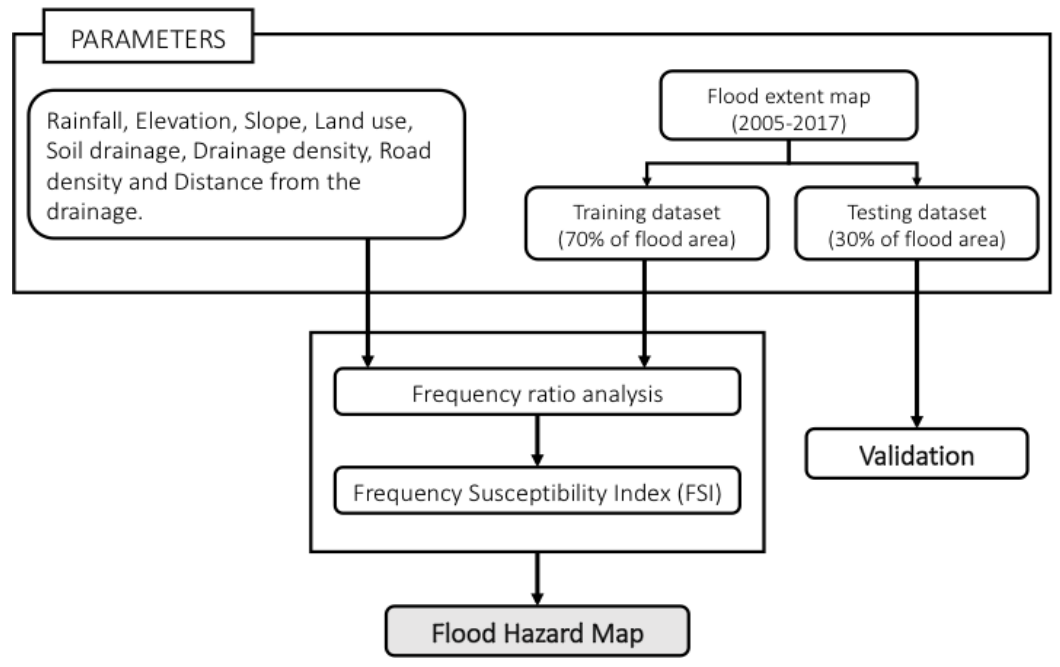

Fig. 3. Flood hazard mapping methodology framework.

\subsection{Flood Extent Map}

The flood extent map was generated from multi-satellite including RADARSAT-2, THAICHOTE, and COSMO-SkyMed-4 obtained from GISTDA for the period of 2005 to 2019 using Geostatistical analyst tool in GIS environment. Seventy percent of flood area was used to generate the flood hazard map while another thirty percent for validation (Seejata et al., 2019).

\subsection{Flood Hazard Map using Frequency Ratio Method}

Geographic Information System (GIS) and Frequency Ratio (FR) method have been used to create flood hazard map. The FR method is a bivariate statistics analysis method based on relationships between historical data and conditioning factors (AlThuwaynee, 2018). It is not only simply implemented but also easy to understand (Khosravi, 2016). The FR is calculated using the following equation (1).

$$
\mathrm{FR}=\frac{P H}{P S}
$$

where PH is the percentage number of flood hazard in each class and PS is the percentage number of study area in each class. 
If FR value is lower than 1 means weak correlation, on the other hand, if the FR value is more than 1 means strong correlation.

The Frequency Susceptibility Index (FSI) is calculated using the following equation (2).

$$
\mathrm{FSI}=\sum_{i=1}^{n} \quad F R_{i}
$$

where $\mathrm{FR}_{i}$ is the value of FR in each factor and $n$ is the number of factors.

In conclusion, the FSI value applied for flood hazard mapping and classified by Jenks natural breaks classification method into 5 classes: (1) very high, (2) high, (3) moderate, (4) low, and (5)very low.

\subsection{Validation Process}

The validation process had been done by the Area Under Curve (AUC). The success rate was calculated using the training flood area of $70 \%$ whereas the prediction accuracy was calculated using a testing flood area of 30\%. The FSI was classified into 100 categories on the x-axis, with a cumulative of flood occurrence on the y-axis (Tehrany et al., 2019).

\section{RESULTS AND DISCUSSIONS}

Table 3 shows observed flood extent for the period of 2005-2019. As can be seen that flood occurred in Muang Sukhothai district almost every year with the severe events, especially in 2006, 2010, 2011 and 2017 (Fig. 4) Among 13 years records, flood extent in Muang district are severe as $78.94 \%, 38.83 \%, 55.10 \%, 49.68 \%$ of the total district area in 2006, 2010, 2011, and 2017, respectively (Tab. 3). This shows that it is needed to have the preparedness and response plan to cope with flood over the district.

Flood area during 2005-2019.

\begin{tabular}{|c|c|c|}
\hline Year & Area $\left(\mathbf{k m}^{2}\right)$ & \% of Flooding area \\
\hline 2005 & 156.683 & 26.95 \\
\hline 2006 & 458.996 & 78.94 \\
\hline 2007 & 141.625 & 24.36 \\
\hline 2008 & 85.227 & 14.66 \\
\hline 2009 & 88.147 & 15.16 \\
\hline 2010 & 225.807 & 38.83 \\
\hline 2011 & 320.403 & 55.10 \\
\hline 2012 & 170.973 & 29.40 \\
\hline 2013 & 124.257 & 21.37 \\
\hline 2014 & 103.867 & 17.86 \\
\hline 2016 & 123.956 & 21.32 \\
\hline 2017 & 288.885 & 49.68 \\
\hline 2019 & 65.890 & 11.33 \\
\hline
\end{tabular}



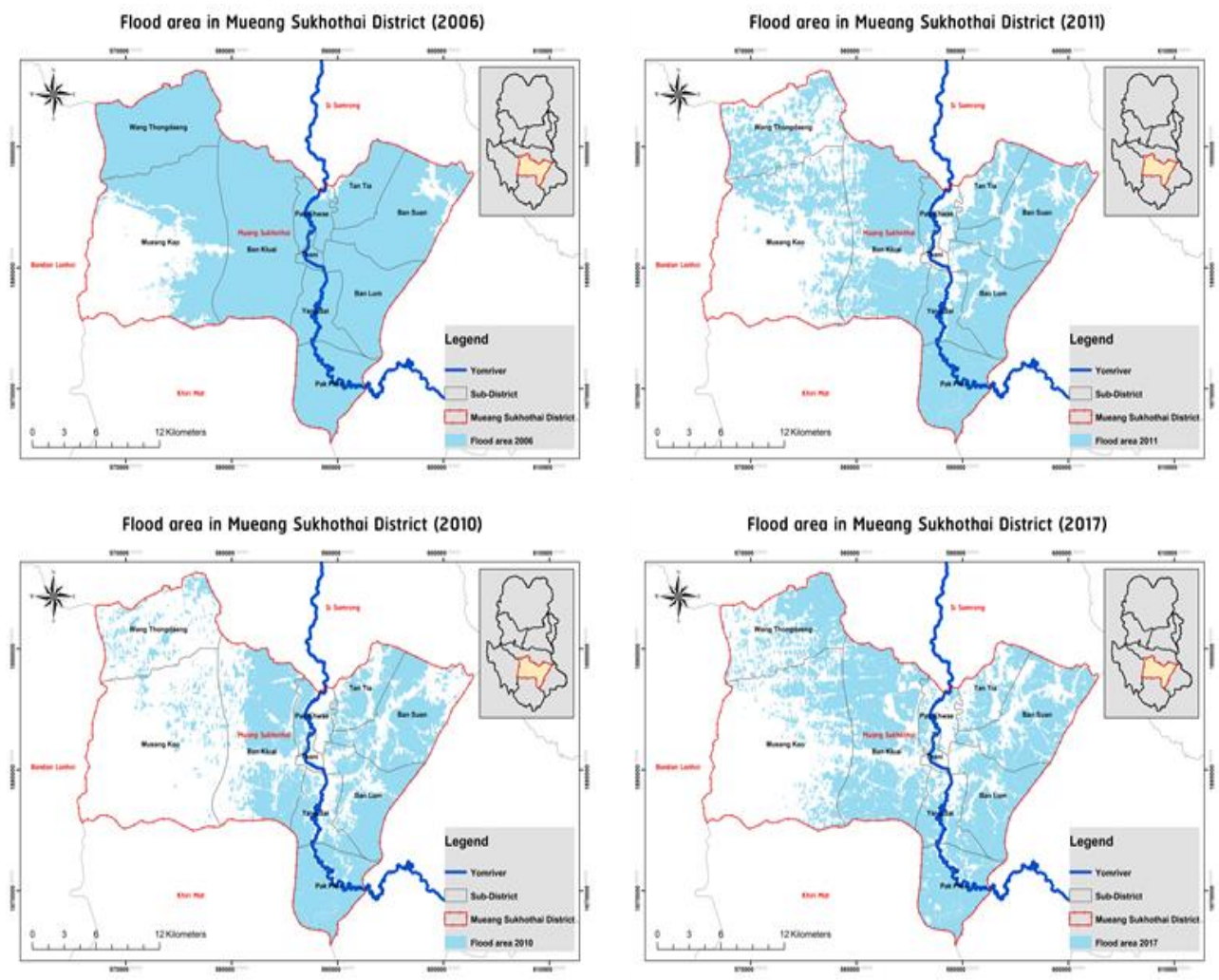

Fig. 4. Observed flood extent for severe events.

By using the frequency ratio method, the obtained flood hazard map is shown in Fig. 5 and Table 4 demonstrates the percentage of each level of flood hazard. It has been found that area with very high flood risk is $88.87 \%$ of the whole district.

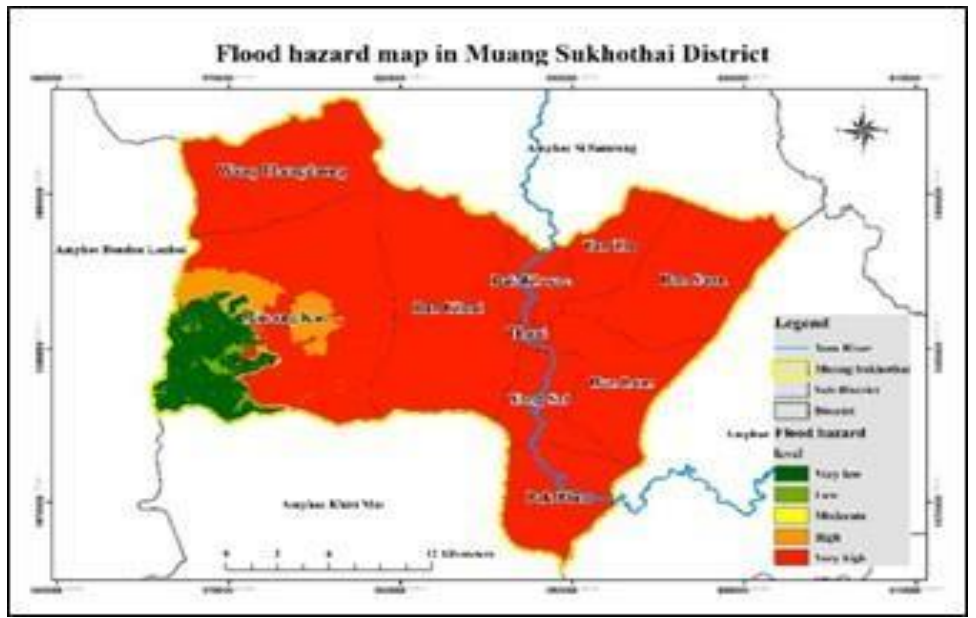

Fig. 5. Flood hazard map in Muang Sukhothai District. 
Table 4.

Flood hazard classification in Muang Sukhothai District.

\begin{tabular}{|c|c|c|}
\hline Level & $\begin{array}{c}\text { Area } \\
(\mathbf{k m 2})\end{array}$ & $\mathbf{\%}$ \\
\hline Very Low & 34.24 & 6.19 \\
\hline Low & 5.14 & 0.93 \\
\hline Moderate & 0.91 & 0.16 \\
\hline High & 21.23 & 3.084 \\
\hline Very High & 491.37 & 88.87 \\
\hline
\end{tabular}

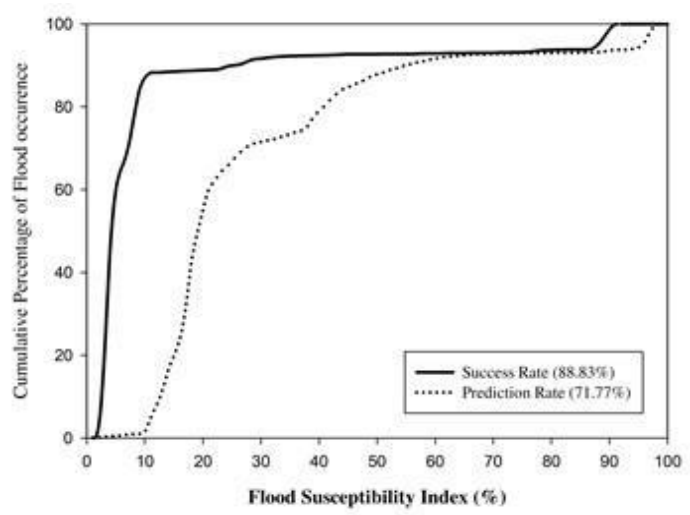

Fig. 6. Success rate and prediction rate curve of the frequency ratio model.

The Area Under Curve (AUC) was used to examine the accuracy of the flood hazard map. Flood Susceptibility Index (FSI) was classified into 100 categories on the x-axis, while a cumulative of flood occurrence was shown on the y-axis. For the frequency ratio model, it has been found that AUC of the training area was $88.83 \%$ and the testing area was $71.77 \%$ (Fig. 6). In order to mitigate flood disaster in Muang Sukhothai district, it is important not only to promote structural measure by constructing flood control facilities such as levee or floodwall but also to prepare non-structural measures by improving ways to communicate disaster information and evacuation as well as by increasing public awareness towards disaster prevention because there is a possibility that a levee or floodwall can breach if the flood exceeds its designed capacity. For these reasons, flood extent map and flood hazard map should be disclosed as a part of flood control measures and flood emergency response plan.

\section{CONCLUSIONS}

The method of flood frequency analysis can be an alternative for flood hazard map generating. With the case study of Muang Sukhothai district, the obtained accuracy of this method is $88.83 \%$. Although, Muang Sukhothai district has floodwall and sandbags to prevent the overflowing in urban area, sometimes it was at risks of collapsing. Therefore, "Flood Hazard Mapping Manual" will be delivered to local officer with the aims of minimizing flood damage by providing residents with inundation-related information in an easy-to-understand way. The manual will describe how to prepare a flood hazard map by coupling frequency analysis with GIS step by step. And that the local officer can easily 
develop by themselves. As can be seen that flood hazard map proves it can uncover and identify risk areas that exist in the district as the basic information for risk-based decisions. However, further develop should be done as follows: evacuation information, communication system during disaster, disaster tracking system, disaster quantify process, allocate mitigation measures, as well as the effectiveness verification system.

\section{ACKNOWLEDGEMENTS}

This research was supported by "Advancing Co-design of Integrated Strategies with Adaptation to Climate Change in Thailand (ADAP-T)" supported by the Science and Technology Research Partnership for Sustainable Development (SATREPS), JST-JICA. Thanks Assist. Prof. Dr. Nattapon Mahavik for his contribution on the method used in the analysis. Thanks khun Prasopsook Suksawan, Mueang Sukhothai Thani Municipality, GeoInformatics and Space Technology Development Agency (GISTDA), Thai Meteorological Department, and Land Development Department for providing various datasets for this research.

\section{REFERENCES}

Alaghmand, S., Bin-Abdullah, R., Abustan, I. \& Vosoogh, B. (2010) GIS-based River Flood Hazard Mapping in Urban Area: A Case Study in Kayu Ara River Basin, Malaysia. Int. J. Eng. Technol, 2, 488-500.

AltThuwaynee, O. (2018) How to Produce Prediction Map in GIS with ArcGIS and Excel. Available from: https://www.udemy.com/user/omar-f-althuwaynee/. [Accessed December 2019].

Anucharn, T. \& Iamchuen, N. (2017) Flood Susceptibility Map Based on Frequency Ratio Method at Songkhla Lake Basin in the Southern of Thailand. BURAPHA SCIENCE JOURNAL, 22(3), 106122.

Cao, C., Xu, P., Wang, Y., Chen, J., Zheng, L. \& Niu, C. (2016) Flash Flood Hazard Susceptibility Mapping Using Frequency Ratio and Statistical Index Methods in Coalmine Subsidence Areas. Sustainability, 8(9), 948.

Dadson, S. J., Hall, J. W., Murgatroyd, A., Acreman, M., Bates, P., Beven, K., \& O'Connell, E. (2017) A restatement of the natural science evidence concerning catchment-based 'natural' flood management in the UK. Proceedings of the Royal Society of London. Series A, Mathematical and Physical Sciences, 473 (2199).

Das, S. (2019) Geospatial mapping of flood susceptibility and hydro-geomorphic response to the floods in Ulhas basin, India. Remote Sensing Applications: Society and Environment, 14, 60-74.

Dihn, Q., Balica, S., Popescu, I. \& Jonoski, A. (2012) Climate change impact on flood hazard, vulnerability and risk of the Long Xuyen Quadrangle in the Mekong Delta. Int. J. River Basin Manag, 10, 103-120.

Duangpiboon, S., Suteerasak, T., Rattanakom, R. \& Towanlong, W. (2018) Flood Susceptibility Mapping Using Geographic Information System and Frequency Ratio Analysis in the Lang Suan Watershed, Southern Thailand. The Journal of King Mongkut's University of Technology North Bangkok, 28(2), 259-272.

Fitzpatrick, F.A., Diebel, M.W., Harris, M.A., Arnold, T.L., Lutz, M.A. \& Richards, K.D. (2005) Effects of urbanization on the geomorphology, habitat, hydrology, and fish index of biotic integrity of streams in the Chicago area, Illinois and Wisconsin. American Fisheries Society Symposium, 47, 87-115.

Haidu, I., \& Ivan, K. (2016a). Évolution du ruissellement et du volume d'eau ruisselé en surface urbaine. Étude de cas: Bordeaux 1984-2014, France. La Houille Blanche, 5, 51-56. 
Haidu I., Ivan K. (2016b) The assessment of the impact induced by the increase of impervious areas on surface runoff. Case study the city of Cluj-Napoca, Romania. Carpathian Journal of Earth and Environmental Sciences, 11(2), 331-337.

Khosravi, K., Nohani, E., Maroufinia, E. \& Pourghasemi, H. R. (2016) A GIS-based flood susceptibility assessment and its mapping in Iran: a comparison between frequency ratio and weights-of-evidence bivariate statistical models with multi-criteria decision-making technique. Natural Hazards, 83(2), 947-987.

Kidson, R. \& Richards, K. S. (2005) Flood frequency analysis: Assumptions and alternatives. Progress in Physical Geography, 29(3), 392-410.

Lee, S., Lee, S., Lee, M. J. \& Jung, H. S. (2018) Spatial assessment of urban flood susceptibility using data mining and geographic information System (GIS) tools. Sustainability, 10(3), 648.

Klemešová, K., Kolář, M. \& Andráško, I., (2014) Uing GIS in the flood management - Flood maps (Troubky, Czech Republic). Geographia Technica, 9(2), 44-53.

Kumar, D. S., Arya, D. S. \& Vojinovic, Z. (2013) Modeling of urban growth dynamics and its impact on surface runoff characteristics. Comput Environ Urban Syst, 41, 124-135.

Nusit, K., Tantanee, S., Subsomboon, K., Leungvichcharoen, S. \& Yiemwattana, S. (2019). The design of flood protection along Nan river, Phitsanulok Province, Thailand. Geographia Technica, 14, Special Issue, 129-137.

Ouma, Y. \& Tateishi, R. (2014) Urban Flood Vulnerability and Risk Mapping Using Integrated MultiParametric AHP and GIS: Methodological Overview and Case Study Assessment. Water, 6, 15151545.

Pelling, M. (2003) The vulnerability of cities: Natural disasters and social resilience, London.

Pakorn, P., Blanken, P. D., Ekkawatpanit, C. \& Hussein, K. (2010) Hydrological impacts of land use/land cover change in a large river basin in central-northern Thailand. International Journal of Climatology, 30(13), 1917-1930.

Sahana, M. \& Patel, P. P. (2019). A comparison of frequency ratio and fuzzy logic models for flood susceptibility assessment of the lower Kosi River Basin in India. Environmental Earth Sciences, 78(10), 289.

Samanta, R. K., Bhunia, G. S., Shit, P. K. \& Pourghasemi, H. R. (2018). Flood susceptibility mapping using geospatial frequency ratio technique: A case study of Subarnarekha River Basin, India. Modeling Earth Systems and Environment, 4(1), 395-408.

Samanta, S., Pal, D. K. \& Palsamanta, B. (2018) Flood susceptibility analysis through remote sensing, GIS and frequency ratio model. Applied Water Science, 8(2), 66.

Shafapour Tehrany, M., Kumar, L., Neamah Jebur, M. \& Shabani, F. (2019) Evaluating the application of the statistical index method in flood susceptibility mapping and its comparison with frequency ratio and logistic regression methods. Geomatics, Natural Hazards and Risk, 10(1), 79-101.

Srijata, C., Yodying, A., Chatsudarat, S., Chidburee, P., Mahavik, N., Kongmuang, C. \& Tantanee, S. (2019) Assessment of Flood Hazard using Geospatial Data and Frequency Ratio Model in Sukhothai Province, Thailand. Proceeding of Asian Conference on Remote Sensing 2019, South Korea.

Sriariyawat, A., Pakoksung, k., Sayama, T., Tanaka, S. \& Koontanakulvong, S. (2013) Approach to estimate the flood damage in Sukhothai Province using flood simulation. Journal of Disaster Research, 8(3), 406-414.

Şarpe, C.A., \& Haidu, I., (2017) Temporal sampling conditions in numerical integration of hydrological systems time series. Geographia Technica, 12(1), 82- 94,

DOI: 10.21163/GT_2017.121.09

Tehrany, M. S., Pradhan, B. \& Jebur, M. N. (2015) Flood susceptibility analysis and its verification using a novel ensemble support vector machine and frequency ratio method. Stochastic Environmental Research and Risk Assessment, 29(4), 1149-1165.

Youssef, A. M., Pradhan, B. \& Sefry, S. A. (2016) Flash flood susceptibility assessment in Jeddah city (Kingdom of Saudi Arabia) using bivariate and multivariate statistical models. Environmental Earth Sciences, 75, 1-16. 